\title{
Pengaruh Inflasi, Produk Domestik Regional Bruto Dan Investasi Terhadap Pengangguran Terdidik Di Provinsi Aceh
}

Linda Wahyuni ${ }^{\text {a1 }}$, Murtala ${ }^{\text {a2 }}$

${ }^{\text {a }}$ Fakultas Ekonomi dan Bisnis Universitas Malikussaleh

1 Corresponding author : lindawahyuni574@gamil.com

2 murtala@unimal.ac.id

Keywords:

Inflation, GRDP, Investment, Uneducated Unemployment.
This study aims to analyze the effect of inflation, GDP, and investment on educated unemployment in Aceh province from 2008 to 2018. The data used in this study are Panel data. The method used to analyze the relationship between the independent variable and the dependent variable is the panel data regression method. The results partially show that inflation has a positive and significant effect on educated unemployment in the Government of Aceh Province, PDRB has a positive and significant effect on educated unemployment in the Government of Aceh Province, and Investment has a negative and significant effect on educated unemployment in the Government of Aceh Province. Simultaneously, Inflation, GRDP, and Investment have a negative and significant effect on Educated Unemployment in the Government of Aceh Province.

\section{PENDAHULUAN}

Meningkatkan jumlah penduduk di Indonesia memicu terjadinya peningkatan jumlah pengangguran jika tidak diikuti dengan lapangan pekerjaan yang memadai, (Bps, 2019). Pengangguran terjadi karena jumlah angkatan kerja atau pencari kerja tidak sebanding dengan jumlah lapangan kerja yang ada. Ketimpangan dalam mendapatkan kesempatan kerja akan berdampak pada meningkatkan tingkat pengangguran pengangguran paling tinggi yaitu pengangguran berpendidikan.

Tabel 1.1

Pengangguran di Provinsi Aceh (\%)

\begin{tabular}{|l|l|r|r|r|r|}
\hline No & Tahun & $\begin{array}{c}\text { Aceh } \\
\text { Timur }\end{array}$ & $\begin{array}{c}\text { Aceh } \\
\text { Utara }\end{array}$ & $\begin{array}{c}\text { Aceh } \\
\text { Taminag }\end{array}$ & Lhokseumawe \\
\hline 1 & 2014 & 10.61 & 13.58 & 9.75 & 11.23 \\
\hline 2 & 2015 & 13.89 & 17.05 & 14.03 & 13.06 \\
\hline 3 & 2016 & 12.25 & 15.32 & 11.89 & 12.15 \\
\hline 4 & 2017 & 13.07 & 16.18 & 12.96 & 12.60 \\
\hline 5 & 2018 & 12.66 & 15.75 & 12.43 & 12.37 \\
\hline
\end{tabular}

Sumber: BPS, (2020)

Berdasarkan Tabel 1.1 di atas menunjukkan bahwa tingkat pengangguran terdidik pada empat Kabupaten /kota dalam provinsi Aceh cenderung berfluktusi, meskipun demikian pada 2018 dari_ keempat Kabupaten/Kota tersebut mengalami penurunan. Penurunan tersebut bisa di sebabkan oleh adanya penambahan tenaga kerja sektor pertanian yang berdampak pada meningkatnya produk domestic regional bruto.

Tabel 1.2

Inflasi di Provinsi Aceh (\%)

\begin{tabular}{|l|l|r|r|r|r|}
\hline No & Tahun & $\begin{array}{c}\text { Aceh } \\
\text { Timur }\end{array}$ & $\begin{array}{c}\text { Aceh } \\
\text { Utara }\end{array}$ & $\begin{array}{c}\text { Aceh } \\
\text { Taminag }\end{array}$ & Lhokseumawe \\
\hline 1 & 2014 & 6.55 & 8.09 & 7.83 & 8.27 \\
\hline 2 & 2015 & 5.09 & 3.35 & 7.11 & 8.53 \\
\hline 3 & 2016 & 4.32 & 3.02 & 7.47 & 8.40 \\
\hline 4 & 2017 & 4.87 & 3.61 & 7.29 & 8.47 \\
\hline 5 & 2018 & 5.03 & 3.45 & 7.38 & 8.43 \\
\hline
\end{tabular}

Sumber: Badan Pusat Statistik, (2020)

Berdasarkan Tabel 1.2 di atas menunjukkan bahwa inflasi tertinggi terjadi pada Kota Lhokseumawe sementara inflasi terendah terjadi pada Kabupaten Aceh Utara. penyebab utama tingginya inflasi di Kota Lhokseumawe adalah karena adanya kenaikan berbagai harga jenis ikan dan kemudian juga sumbangan kenaikan harga emas perhiasan. 
Tabel 1.3

PDRB di Provinsi Aceh (Milyar)

\begin{tabular}{|l|l|c|c|c|r|}
\hline No & Tahun & $\begin{array}{c}\text { Aceh } \\
\text { Timur }\end{array}$ & Aceh Utara & $\begin{array}{c}\text { Aceh } \\
\text { Taminag }\end{array}$ & Lhokseumawe \\
\hline 1 & 2014 & $8,694,868$ & $19,940,745$ & $5,647,697$ & $9,321,038$ \\
\hline 2 & 2015 & $8,195,726$ & $16,339,922$ & $5,763,172$ & $7,635,732$ \\
\hline 3 & 2016 & $8,509,753$ & $16,694,901$ & $6,063,471$ & $7,728,897$ \\
\hline 4 & 2017 & $9,087,955$ & $17,659,442$ & $6,516,651$ & $8,070,950$ \\
\hline 5 & 2018 & $8,798,854$ & $17,177,171$ & $6,290,061$ & $7,899,924$ \\
\hline
\end{tabular}

Sumber : BPS, (2020)

Berdasarkan Tabel 1.3 di atas menunjukkan bahwa penerimaan PDRB tertinggi pada Kabupaten Aceh Utara sementara PDRB paling rendah yaitu pada Kabupaten Aceh Tamiang. PDRB Aceh Utara di dukung oleh penerimaan dari sektor pertanian. Dimana Kabupaten Aceh Utara adalah sebuah kabupaten yang paling luas dan memiliki area pertanian paling luas. Huda,dkk (2018), Parwata,dkk (2016), Sarimuda, dkk (2014), menyatakan bahwa semakin tinggi PDRB, maka Pengangguran Terdidik akan mengalami kenaikan.

\section{Tabel 1.4}

\section{Investasi di Provinsi Aceh (Milyar)}

\begin{tabular}{|l|l|r|r|r|r|}
\hline No & Tahun & $\begin{array}{c}\text { Aceh } \\
\text { Timur }\end{array}$ & \multicolumn{1}{c|}{$\begin{array}{c}\text { Aceh } \\
\text { Utara }\end{array}$} & $\begin{array}{c}\text { Aceh } \\
\text { Taminag }\end{array}$ & Lhokseumawe \\
\hline 1 & 2014 & 116,230 & 20,434 & 80,301 & 99,284 \\
\hline 2 & 2015 & 266,744 & 316,323 & 393,368 & 520,022 \\
\hline 3 & 2016 & 108,000 & 3,324 & 0 & $1,174,759$ \\
\hline 4 & 2017 & 14,663 & 23,363 & 152,455 & 273,359 \\
\hline 5 & 2018 & 14,771 & 26,687 & 152,455 & $1,448,118$ \\
\hline
\end{tabular}

Sumber : BPS, (2020)

Berdasarkan Tabel 1.4 di atas menunjukkan bahwa investasi tertinggi yaitu pada Pemerintah Kota Lhokseumawe sementara Aceh Utara paling rendah tingkat investasinya. Investasi mempengaruhi pengangguran terdidik dari sisi penawaran. Semakin besar investasi maka peluang jumlah pekerja yang digunakan dalam menghasilkan barang dan jasa akan meningkat, sehingga peluang pembukaan lapangan pekerjaan akan semakin besar.

Penelitian ini bertujuan untuk mengetahui dan pengaruh dari inflasi, produk domestic regional bruto dan investasi terhadap pengangguran terdidik di Provinsi Aceh.

Selanjutnya bagian kedua dari penelitian ini akan membahas tinjauan teoritis, metode penelitian akan dibahas pada bagian ketiga. Kemudian pada bagian ke empat akan dibahas hasil penelitian dan pembahasan. Pada bagian kelima akan membahas kesimpulan dan saran.

\section{TINJAUAN TEORITIS Pengangguran Terdidik}

Pengangguran terdidik merupakan para pelajar yang sudah selesai pendidikan dan ingin mendapatkan kerjaan namun belum memperolehnya. Pengangguran ini memiliki kaitana erat dengan pendidikan yang ada di Negara berkembang, yang berkisar pada pandangan masyarakat, (Tobing, 2004).

Pengangguran adalah orang yang sudah termasuk angkatan kerja, secara aktif sedang mencari pekerjaan, tetapi tidak mendapat pekerjaan yang diinginkannya (Sukirno, 2000).

Pengangguran merupakan masalah makro ekonomi yang berpengaruh terhadap manusia. Kebanyakan orang akan kehilangan pekerjaan dan mengakibatkan pada menurunnya standar kehidupan mereka (Mankiw, 2000).

\section{Inflasi}

Inflasi merupakan proses meningkatnya harga barang dalam perekonomian. Tingkat inflasi berbeda dari satu periode ke periode lain dan berbeda pula dari satu negara ke negara lain (sukirno, 2008).

Inflasi merupakan suatu kejadian yang menggambarkan situasi dan kondisi dimana harga barang mengalami kenaikan dan kurs mengalami pelemahan, (Zakaria, 2013).

Inflasi akan menjatuhkan harga saham di pasar. Sedangkan inflasi yang lemah dapat berakibat pada lambatnya pertumbuhan ekonomi dan akhirnya harga saham akan bergerak dengan lambat (Samsul, 2006).

\section{Produk Domestik Regional Bruto}

PDRB adalah total dari barang dan jasa yang diproduksi dalam jangka waktu tertentu. 
PDRB menghitung hasil produksi tanpa melihat siapa pemilik dari faktor produksi tersebut (Sadono, 2010).

PDRB merupakan jumlah produk barang dan jasa yang dihasilkan suatu negara dalam satu tahun. (Mankiw, 2007).

PDRB adalah barang dan jasa yang diproduksi pada suatu wilayah negara yang bersangkutan,biasanya dalam satu tahun (Prasetyo, 2011).

\section{Investasi}

Investasi adalah komitmen atas sejumlah dana atau sumber daya lainnya yang dilakukan sekarang, dengan tujuan memperoleh sejumlah keuntungan di masa depan (Tandelilin, 2010).

Investasi merupakan sebuah pengeluaran atau pembelanjaan penanaman suatu modal atau perusahaan untuk membeli barang-barang modal dan juga mesin-mesin produksi untuk menambah kemampuan memproduksi barang-barang dan juga jasa-jasa yang tersedia dalam perekonomian (Sukirno, 2012).

Menurut Sadono (2004) dalam investasi terdapat dua tipe investasi yaitu sebagai berikut :

a) Investasi yang terdorong yaitu investasi yang tidak diadakan akibat penambahan permintaan, pertambahan permintaan yang diakibatkan pertambahan pendapatan.

b) Investasi otonomi yaitu investasi yang dilaksanakan atau diadakan secara bebas, artinya investasi yang diadakan bukan karena pertambahan permintaan efektif.

\section{Kerangka Konseptual}

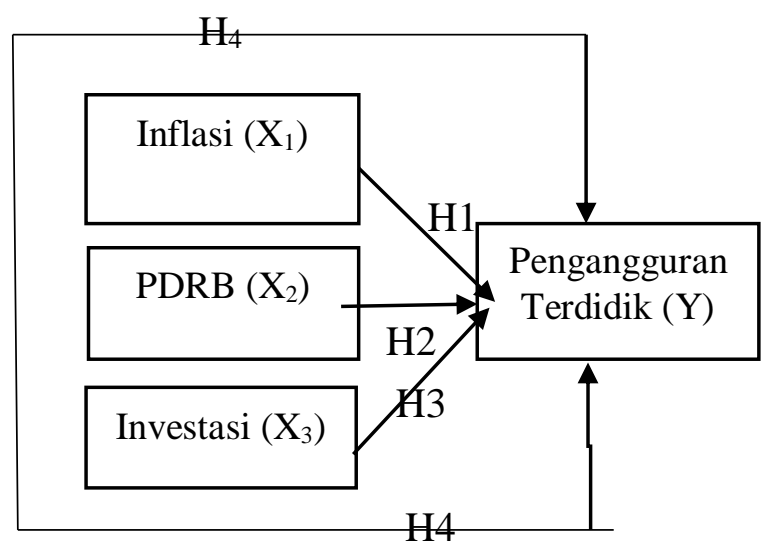

Gambar 1.

Kerangka Konseptual
Kerangka konseptual gambar 1 di atas menjelaskan pengaruh antara variabel bebas dan variabel terikat, yaitu pengaruh Inflasi (x1), PDRB (x2) dan Investasi (x3) terhadap Pengangguran Terdidik (y).

\section{Hipotesis}

Adapun hipotesis alternatif yang diberikan adalah sebagai berikut :

$\mathrm{H}_{1}=$ Inflasi berpengaruh terhadap Pengangguran Terdidik

$\mathrm{H}_{2}=$ PDRB berpengaruh terhadap Pengangguran Terdidik

$\mathrm{H}_{3}=$ Investasi berpengaruh terhadap Pengangguran Terdidik

$\mathrm{H}_{4}=$ Inflasi, PDRB dan Investasi berpengaruh terhadap Pengangguran Terdidik

\section{METODE PENELITIAN}

\section{Data dan Sumber Data}

Penelitian ini menggunakan data sekunder, data sekunder adalah data yang telah diolah oleh pihak lain. Data yang digunakan tahun 2008-2018. Data utama di dalam penulisan ini berasal dari BPS.

\section{Definisi Operasionalisasi Variabel}

Operasionalisasi variabel merupakan petunjuk bagaimana variabel dalam penelitian diukur.

a. Pengangguran terdidik adalah orang yang telah lulus pendidikan tetapi belum bekerja (Jiwa).

b. Inflasi adalah proses terjadinya kenaikan harga-harga secara umum dan secara terus menerus (persen).

c. PDRB merupakan keseluruhan nilai tambah dari semua kegiatan perekonomian dalam waktu satu tahun (Rp).

d. Investasi adalah kegiatan penanam modal (Rp).

\section{Uji Normalitas}

Menurut Sunyoto (2011), uji normalitas adalah pengujian yang menguji data $(\mathrm{x})$ dan (y) yang dihasilkan berdistribusi normal atau tidak normal. 
Jika nilai probabilitasnya lebih besar dari $5 \%(<0,05)$, berarti nilai residual berdistribusi normal. Sebaliknya, jika nilai probabilitas lebih kecil dari 5\% $(<0,05)$, berarti nilai residualnya berdistribusi tidak normal.

\section{Pengujian Asumsi Klasik}

\section{Uji Multikolineritas}

Multikolineritas adalah proses terjadinya korelasi yang kuat diantara variabel-variabel (x) yang di ikut sertakan dalam pembentukan regresi linear (Gujarati, 2006).

Untuk mengetahui multikolineritas dengan menggunakan Eviews dapat dilakukan dengan melihat korelasi sesame variabel bebas (Correlation Matrik). Jika korelasi antara variabel bebas $<0,8$, berarti tidak terjadi multikolineritas.

\section{Uji Heteroskedastisitas}

Heteroskedastisitas adalah uji yang menilai ada ketidaksamaan varian dari residual semua pengamatan. Menurut (Widarjono, 2013), Heteroskedastisitas dapat dilihat pada nilai probabilitas Obs*R-squared. Jika nilai probabilitas Obs*R-squared $>5 \%$ maka tidak adanya heteroskedastisitas.

\section{Model Regresi Data Panel}

\section{Common Effect Model (CEM)}

Model common effect menyatukan
data cross section dengan time series (Widarjono, 2009).

\section{Fixed Effect Model (FEM)}

Model fixed effect adalah model dengan intercept berbeda-beda untuk setiap subjek (cross section (Gujarati, 2012).

\section{Random Effect Model (REM)}

$$
\text { Menurut (Widarjono, }
$$

model random effect digunakan untuk mengatasi kelemahan model fixed effect yang menggunakan variabel dummy.
Chow test yaitu membandingkan model common effect dengan fixed effect (Widarjono, 2009).

a. Apabila nilai signifikan $<5 \%$ maka yang terbaik adalah FEM.

b. Apabila nilai signifikansi $>5 \%$ yang terbaik adalah CEM.

\section{Hausman Test}

Membandingkan fixed effect dengan random effect (Gujarati, 2012).

a. Apabila nilai signifikansi $<5 \%$ maka model yang terbaik adalah FEM.

b. Apabila nilai signifikansi $>5 \%$ maka model yang terbaik adalah REM.

\section{Analisis Regresi Data Panel}

Model ini dipilih karena penelitian ini dirancang untuk menentukan variabel bebas yang mempunyai pengaruh terhadap variabel terikat.

$$
\mathrm{PT}_{\mathrm{it}}=\beta_{0}+\beta_{1} \mathrm{INF}_{\mathrm{it}}+\beta_{2} \mathrm{PDRB}_{\mathrm{it}}+\beta_{3} \mathrm{INV}_{\mathrm{it}}+\mathrm{e}_{\mathrm{it}}
$$

Dimana:

Y : Pengangguran Terdidik

$\mathrm{X} 1 \quad$ : Inflasi

$\mathrm{X} 2$ : PDRB

$\mathrm{X} 3$ : Investasi

B0 : Konstanta

e : Error Team

\section{Pengujian Statistik}

\section{Uji t-Statistik}

Menurut Ghozali (2006), uji statistic atau uji $\mathrm{t}$ bertujuan untuk melihat signifikan dari pengaruh variabel ( $\mathrm{x}$ ) variabel (y) dengan menganggap variabel bebas lainnya adalah konstan.

1. Jika $\mathrm{t}$ hitung $>\mathrm{t}$ tabel, maka variabel penjelas secara individual mempengaruhi variabel yang dijelaskan secara signifikan.

2. Jika $\mathrm{t}$ hitung $<\mathrm{t}$ tabel, maka variabel penjelas secara individual tidak mempengaruhi variabel yag dijelaskan secara signifikan

3. 


\section{Uji F-statistik}

Untuk menentukan tingkat signifikan secara keseluruhan pada tingkat kepercayaan sebesar 95\%, pengujian hipotesis dengan uji $\mathrm{F}$. Gujarati (2006), uji F dilakukan dengan membandingkan antara $\mathrm{F}$ hitung dengan $\mathrm{F}$ table, apabila $\mathrm{F}$ hitung $>\mathrm{F}$ table, dengan taraf signifikan $5 \%$, artinya $\left(\mathrm{X}_{1}\right),\left(\mathrm{X}_{2}\right)$, dan $\left(\mathrm{X}_{3}\right)$, secara bersamasama mempengaruhi (Y).

\section{Koefisien Determinasi $\left(\mathbf{R}^{\mathbf{2}}\right)$}

Koefisien ini nilainya antara 0-1. Bila nilai koefisien dterminasi yang diberi symbol $\mathrm{R}^{2}$ mendekati angka1, maka variabel (x) makin mendekati hubungan dengan variabel (y) (Gujarati, 2009).

\section{HASIL PENELITIAN DAN PEMBAHASAN}

\section{Hasil Penelitian}

\section{Hasil Uji Normalitas}

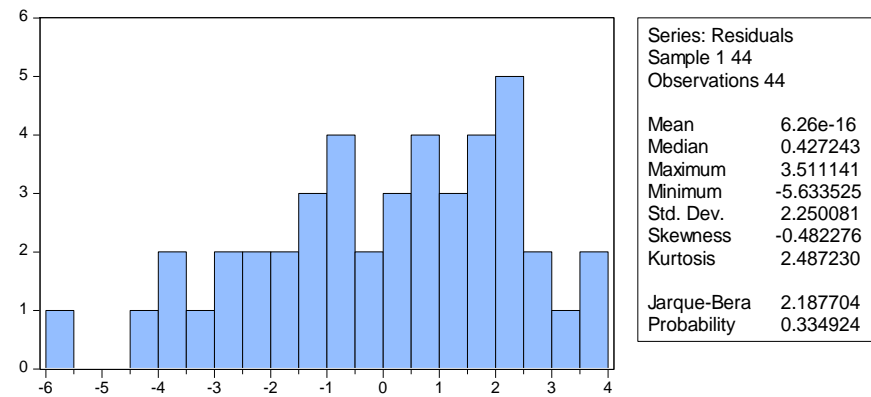

Sumber : Data diolah (2020)

Gambar 2

\section{Histogram-Hasil Uji Normalitas}

Untuk mengetahui normal atau tidak normalnya model regresi variabel pengganggu yaitu dengan cara membandingkan nilai prob J-B dengan $\alpha=5 \%$. Nilai probability sebesar 0.334924 $>5 \%$ sehingga dapat diartikan bahwa data berdistribusi normal.

\section{Hasil Uji Asumsi Klasik}

\section{Uji Multikoliniearitas}

Adapun hasil pengujian sebagai berikut :

\section{Tabel 1.5}

\section{Hasil Uji Multikoliniearitas}

\begin{tabular}{|c|c|c|c|}
\hline & INFLASI & PDRB & INVESTASI \\
\hline INFLASI & 1 & -0.1542154270148004 & 0.2686954810283898 \\
\hline PDRB & -0.1542154270148004 & 1 & 0.02650264200975865 \\
\hline INVESTASI & 0.2686954810283898 & 0.02650264200975865 & 1 \\
\hline
\end{tabular}

Sumber : Hasil Olah Data,2020

Tabel diatas terlihat bahwa tidak terdapat variabel yang memiliki nilai lebih dari 0,8. maka dalam tidak terjadi multikolinearitas.

\section{Uji Heteroskedastisitas}

Tabel 1.6

Uji Heteroskedastisitas

\begin{tabular}{|l|l|l|l|}
\hline F-statistic & 0.294841 & Prob. F(1,41) & 0.5901 \\
\hline Obs*R-squared & 0.307016 & Prob. Chi-Square(1) & 0.5795 \\
\hline
\end{tabular}

Sumber: Hasil Penelitian, 2020 (data diolah)

Berdasarkan uji Heteroskedastisitas nilai prob. Chi square (1) pada obs*R-Squared yaitu sebesar 0.5795. Jadi, $0.5795>5 \%$ maka terbebas dari heteroskedastisitas.

\section{Pemilihan Model Data Panel Uji Chow Test}

Tabel

Hasil Uji Chow Test

\begin{tabular}{|l|l|l|r|}
\hline Effects Test & Statistic & d.f. & \multicolumn{1}{c|}{ Prob. } \\
\hline Cross-section F & 3.269589 & $(3,161)$ & 0.0228 \\
\hline Cross-section Chi-square & 9.935562 & 3 & 0.0191 \\
\hline
\end{tabular}

Sumber : Data Diolah (2020)

Berdasarkan Tabel di atas, menunjukkan bahwa nilai probability baris Chi Square pada uji chow adalah sebesar 0,019. Nilai tersebut $<0,05$. Apabila nilai probalibility chi square $<5 \%$,yang terbaik adalah FEM.

\section{Uji Hausmant Test}

Tabel 1.7

Hasil Uji Hausman

\begin{tabular}{|l|c|c|c|}
\hline $\begin{array}{l}\text { Test } \\
\text { Summary }\end{array}$ & $\begin{array}{c}\text { Chi-Sq. } \\
\text { Statistic }\end{array}$ & $\begin{array}{c}\text { Chi-Sq. } \\
\text { d.f. }\end{array}$ & Prob. \\
\hline $\begin{array}{c}\text { Cross-section } \\
\text { random }\end{array}$ & 9.808768 & 3 & 0.0203 \\
\hline
\end{tabular}

Sumber : Data Diolah (2020)

Terlihat nilai probabilitasnya adalah sebesar 0,0203 . Nilai tersebut berada dibawah tingkat 
kesalahan yaitu 0,05. Berdasarkan uji hausman, model terbaik adalah FEM.

\section{Analisis Regresi Data Panel}

Model terbaik adalah FEM karena berdasarkan uji chow test dan uji hausmant nilai signifikan $<0,05$. FEM bertujuan untuk melihat adanya pengaruh antara variabel infasi, PDRB dan Infestasi terhadap pengangguran terdidik Hasil FEM adalah sebagai berikut:

Tabel 1.8 Fixed Effect Model

\begin{tabular}{|c|c|c|c|c|}
\hline \multicolumn{3}{|c|}{ Dependent Variable: Y } & \multirow[b]{2}{*}{ t-Statistic } & \multirow[b]{2}{*}{ Prob. } \\
\hline Variable & Coefficient & Std. Error & & \\
\hline C & -85.84326 & 29.22920 & -2.936901 & 0.0038 \\
\hline $\mathrm{X} 1$ & 0.175508 & 0.060809 & 2.886208 & 0.0044 \\
\hline $\mathrm{LOG}(\mathrm{X} 2)$ & 5.878987 & 1.835244 & 3.203381 & 0.0016 \\
\hline LOG(X3) & -0.226189 & 0.096150 & -2.352451 & 0.0199 \\
\hline \multicolumn{5}{|l|}{ Fixed Effects (Cross) } \\
\hline $\mathrm{AT}-\mathrm{C}$ & -0.115811 & & & \\
\hline$=\mathrm{AU}-\mathrm{C}$ & -1.427585 & & & \\
\hline $\mathrm{ATM}-\mathrm{C}$ & 2.100773 & & & \\
\hline \multirow[t]{2}{*}{ LSM-C } & -0.376925 & & & \\
\hline & \multicolumn{2}{|c|}{ Effects Specification } & & \\
\hline \multicolumn{4}{|c|}{ Cross-section fixed (dummy variables) } & \\
\hline & & & & \\
\hline R-squared & 0.431177 & \multicolumn{2}{|c|}{ Mean dependent var } & 11.80244 \\
\hline Adjusted R-squared & 0.409979 & \multicolumn{2}{|c|}{ S.D. dependent var } & 2.850698 \\
\hline S.E. of regression & 2.189702 & \multicolumn{2}{|c|}{ Akaike info criterion } & 4.446181 \\
\hline Sum squared resid & 771.9617 & \multicolumn{2}{|c|}{ Schwarz criterion } & 4.576347 \\
\hline Log likelihood & -366.4792 & \multicolumn{2}{|c|}{ Hannan-Quinn criter. } & 4.499009 \\
\hline F-statistic & 20.34012 & \multicolumn{2}{|c|}{ Durbin-Watson stat } & 1.573853 \\
\hline Prob(F-statistic) & 0.000000 & & & 0.000000 \\
\hline
\end{tabular}

Sumber : Data Diolah,2020

Berdasarkan Tabel diatas, maka persamaan regresi yang dapat disusun di dalam penelitian ini adalah sebagai berikut :

$\mathrm{Y}=-85.84326+0.175508 \mathrm{X}_{1}+5.878987 \mathrm{X}_{2}$

- $0.226189 \mathrm{X}_{3}$

Berdasarkan persamaan di atas, dapat dijelaskan bahwa :

1. Konstanta sebesar - 85.84326 artinya variabel inflasi, PDRB dan Investasi dianggap bernilai 0 , maka pengangguran terdidik turun sebesar $85.84326 \%$.

2. Nilai koefisien regresi inflasi sebesar 0.175508 menunjukkan hubungan positif (searah) yang memberikan arti jika inflasi meningkat $\quad 1 \%$ menyebabkan pengangguran terdidik meningkat sebesar
$0.175508 \%$, dengan asumsi PDRB dan Investasi bernilai tetap.

3. Nilai koefisien regresi PDRB sebesar 5.878987 menunjukkan hubungan positif (searah) yang memberikan arti bahwa setiap kenaikan PDRB sebesar 1 rupiah menyebabkan pengangguran terdidik meningkat sebesar $5.878987 \%$, dengan asumsi Inflasi dan Investasi bernilai tetap.

4. Nilai koefisien regresi Investasi sebesar 0.226189 menunjukkan hubungan negatif (tidak searah) yang memberikan arti bahwa setiap kenaikan investasi sebesar $1 \%$ menyebabkan pengangguran terdidik menurun sebesar $0.226189 \%$ dengan asumsi Inflasi dan PDRB terbuka bernilai tetap.

5. $\mathrm{Y}=-85.959071+0.175508 \mathrm{X}_{1}+5.878987$ $\mathrm{X}_{2}-0.226189 \mathrm{X}_{3}$

Nilai konstan pada Kabupaten Aceh Timur adalah -85.959071 , artinya apabila inflasi, PDRB dan investasi dianggap bernilai 0 , maka pengangguran terdidik sebesar $85.959071 \%$.

6. $\mathrm{Y}=-87.269945+0.175508 \mathrm{X}_{1}+$

$5.878987 \mathrm{X}_{2}-0.226189 \mathrm{X}_{3}$

Nilai konstan pada Kabupaten Aceh Utara adalah - 87.269945, artinya apabila inflasi, PDRB dan investasi dianggap bernilai 0 , maka akan menurunkan pengangguran terdidik sebesar $87.269945 \%$.

7. $\mathrm{Y}=-83.741587+0.175508 \mathrm{X}_{1}+5.878987$ $\mathrm{X}_{2}-0.226189 \mathrm{X}_{3}$

Nilai konstan pada Kabupaten Aceh Tamiang adalah - 83.741587, artinya apabila inflasi, PDRB dan investasi dianggap bernilai 0 , maka pengangguran terdidik sebesar $83.741587 \%$.

8. $\mathrm{Y}=-86.21955+0.175508 \mathrm{X}_{1}+5.878987$ $\mathrm{X}_{2}-0.226189 \mathrm{X}_{3}$

Nilai konstan pada Kota Lhokseumawe adalah - 86.21955, artinya apabila inflasi, PDRB dan investasi dianggap bernilai 0 , maka akan menurunkan pengangguran terdidik sebesar $86.21955 \%$. 


\section{Hasil Uji t-Statistik}

Uji t digunakan untuk melihat pengaruh variabel independen terhadap variabel dependen secara parsial. Berdasarkan hasil pengujian secara Parsial pada Tabel 4 dapat dijelaskan sebagai berikut:

1. Variabel $\left(\mathrm{X}_{1}\right)$ berpengaruh positif dan signifikanf terhadap (Y). Hal ini dilihat pada nilai $t_{\text {hitung }}>t_{\text {tabel }}$ yakni $2,886>$ 1,661. Dan nilai probabilitas $0.004<$ 0.05 .

2. Variabel $\left(\mathrm{X}_{2}\right)$ berpengaruh positif dan signifikan terhadap (Y). Hal ini didasarkan pada nilai $t_{\text {hitung }}>\mathrm{t}_{\text {tabel }}$ yakni $3,203>1,661$. Dan dari probabilitas $0.0001<0.05$.

3. Variabel $\left(\mathrm{X}_{3}\right)$ berpengaruh secara signifikan dan negatif terhadap (Y). Hali ini didasarkan pada $t_{\text {hitung }}>t_{\text {tabel }}$ yakni 2,352>1,661. Dan dari probabilitas 0.01 $<0.05$.

\section{Hasil Uji F-Statistik}

Priyanto (2013), mengatakan uji f digunakan untuk statistic uji $f$ dengan $\mathrm{Df}_{1}=(\mathrm{k}-1) \mathrm{Df}_{2}=(\mathrm{n}-\mathrm{k}-1)$. Dimana $\mathrm{f}$ tabel diperoleh dari daftar tabel distribusi f dengan $\alpha=$ 0,05. Nilai $F_{\text {hitung }}$ sebesar 20,340 dengan probabilitas 0,0000 , sedangkan $\mathrm{F}_{\text {tabel }}$ pada $\mathrm{df}$ $=(\mathrm{k}-1)(\mathrm{n}-\mathrm{k})=(4-1)(44-4)=(3)(40)$ yaitu 2,701 maka 20,340>2,701. Secara simultan $\left(X_{1}\right),\left(X_{2}\right)$ dan $\left(\mathrm{X}_{3}\right)$ memiliki pengaruh positif dan signifikan terhadap (Y).

\section{Koefisien Determinasi $\mathbf{R}^{2}$.}

Dari uji $R^{2}$ maka yang dilihat dari Ajudted R Square yaitu sebesar 0,4099 . Jadi besarnya pengaruh $\left(\mathrm{X}_{1}\right),\left(\mathrm{X}_{2}\right)$ dan $\left(\mathrm{X}_{3}\right)$ terhadap (Y) 40,99\% . Sedangkan sisanya di pengaruhi oleh variabel lain luar penelitian 59,01\%.

\section{Pembahasan}

\section{Pengaruh Inflasi Terhadap Pengangguran Terdidik di Provinsi Aceh}

Inflasi berpengaruh positif dan signifikan terhadap pengangguran terdidik di Provinsi Aceh. Hasil penelitian ini sesuai dengan penelitian Sari dan Mangkuwinata (2017), bahwa inflasi berpengaruh positif dan signifikan terhadap pengangguran.

\section{Pengaruh PDRB Terhadap Pengangguran Terdidik di Provinsi Aceh}

PDRB berpengaruh positif dan signifikan terhadap pengangguran terdidik di Provinsi Aceh. Hasil penelitian ini sesuai dengan penelitian Mada dan Ashar (2015) yang menyimpulkan bahwa produk domestik regional bruto berpengaruh positif terhadap tingkat pengangguran.

\section{Pengaruh Investasi Terhadap Pengangguran Terdidik di Provinsi Aceh}

Investasi berpengaruh negatif dan signifikan terhadap pengangguran terdidik di Provinsi Aceh. Hasil penelitian ini sesuai dengan penelitian Kurniawan (2010) bahwa investasi berpengaruh negatif terhadap pengangguran.

\section{KESIMPULAN DAN SARAN}

\section{Kesimpulan}

Berdasarkan hasil penelitian dapat diambil kesimpulan antara lain :

1. Secara parsial Inflasi berpengaruh positif dan signifikan terhadap Pengangguran terdidik di Provinsi Aceh.

2. Secara parsial PDRB berpengaruh positif dan signifikan terhadap Pengangguran terdidik di Provinsi Aceh.

3. Secara parsial Investasi berpengaruh negatif dan signifikan terhadap Pengangguran terdidik di Provinsi Aceh.

4. Secara simultan Inflasi, PDRB dan Investasi berpengaruh positif dan signifikan terhadap Pengangguran Terdidik di Provinsi Aceh.

\section{Saran}

Laju inflasi dan tingkat investasi merupakan komponen yang penting dalam menekan tingkat pengangguran. Pemerintah diharapkan bisa menjaga stabilitas laju inflasi agar tetap terkendali. Dengan terjaga dan terkendalinya stabilitas laju inflasi diharapkan dapat menurunkan angka pengangguran

Pemerintah diharapkan bisa menjaga minat para investor agar tetap mau berinvestasi. Dengan terjaganya minat investor untuk berinvestasi diharapkan dapat mengatasi masalah pengangguran. 


\section{DAFTAR PUSTAKA}

BPS. (2019). Diunduh dari www. Badan Pusat Statistik.co.id.

Ghozali, I. (2006). Aplikasi Analisis Multivarite dengan SPSS, Cetakan Keempat. Semarang.

Gujarati, D. (2003). Ekonometrika Dasar.. Erlangga: Jakarta.

Gujarati, D. (2005). Ekonometrika Dasar. Jakarta: Erlangga.

Gujarati, D. (2006). Ekonometri Dasar. Erlangga: Jakarta.

Gujarati, D. (2009). Dasar-dasar Ekonomitrika.Jakarta : Salemba Empat.

Gujarati, Damodar, \& Porter, D. C. (2012). Dasar-Dasar Ekonometrika. Jakarta.

Mada dan Ashar (2015) Analisis Variabel Yang Mempengaruhi Jumlah Pengangguran Terdidik Di Indonesia.

Mankiw, N. G. (2000). Teori Makro Ekonomi (Edisi Ke tiga E; N. Imam, e). Jakarta: Erlangga.

Mankiw, \& N.G. (2007). Makro Ekonomi (Edisi Keenam). Jakarta: Erlangga.

Parwata, Swendra dan Yudiaatmaja (2016) Pengaruh Produk Domestik Regional Bruto (Pdrb) Dan Tingkat Pengangguran Terbuka Terhadap Tingkat Kemiskinan.

Priyanto, D. (2013). Mandiri Belajar Analisi Data Dengan SPSS. Mediakom: Yogyakarta.

Sadono, S. (2004). Makroekonomi Edisi Ketiga. PT Raja Grafindo Persada: Jakarta.

Sadono, S. (2010). Mikro Ekonomi Teori Pengantar. Jakarta: PT. Raja Grafindo Persada.

Samsul, Mohammad. (2006). Pasar Modal dan Manajemen Portofolio. Jakarta: Penerbit Erlangga.
Sari dan Mangkuwinata (2017) Pengaruh Variabel Makro Ekonomi Terhadap Kemiskinan Di Provinsi Aceh

Sarimuda dan Soekarnoto (2014) Pengaruh Pdrb, Umk, Inflasi, Dan Investasi Terhadap Pengangguran Terbuka Di Kab/Kota Provinsi Jawa Timur Tahun 2007 - 2011.

Sukirno, S. (2000). Pengantar Teori Mikro Ekonomi. PT. Raja Grafindo Persada.Jakarta.

Sukirno, S. (2008). Teori Pengantar Makroekonomi edisi 3. PT Raja Grafindo Persada. Jakarta

Sukirno, S. (2012). Teori Pengantar Makro Ekonomi, Edisi Ketiga. PT Raja Grafindo Persada: Jakarta.

Sunyoto, D. (2011). Metodelogi Penelitian Ekonomi. Cetakan Pertama. CAPS: Yogyakarta.

Tandelilin, Eduardus. 2010. Analisis Investasi dan Manajemen Portofolio. Edisi Pertama. Yogyakarta: BPFE.

Widarjono. (2009). Ekonometrika: Pengantar dan Aplikasinya, Ekonomi.

Widarjono. (2013). Ekonometrika: Pengantar dan Aplikasinya, Ekonomi. In Jakarta: Ekonomi. 